\title{
Lipophilic toxins occurrence in non-traditional invertebrate vectors from North Atlantic Waters (Azores, Madeira, and Morocco): Update on geographical tendencies and new challenges for monitoring routines
}

\author{
Marisa Silva ${ }^{\mathrm{a}, \mathrm{b}, *, 1}$, Inés Rodríguez ${ }^{\mathrm{c}, \mathrm{d}, 1}$, Aldo Barreiro ${ }^{\mathrm{b}}$, Manfred Kaufmann ${ }^{\mathrm{b}, \mathrm{e}, \mathrm{f}}$, Ana Isabel Neto ${ }^{\mathrm{b}, \mathrm{g}}$, \\ Meryem Hassouani $^{\mathrm{a}}{ }^{\mathrm{b}}$, Brahim Sabour ${ }^{\mathrm{h}}$, Amparo Alfonso ${ }^{\mathrm{d}}$, Luis M. Botana ${ }^{\mathrm{d}}$, Vitor Vasconcelos ${ }^{\mathrm{a}, \mathrm{b}}$ \\ ${ }^{a}$ Department of Biology, Faculty of Sciences, University of Porto, Rua do Campo Alegre, Porto 4619-007, Portugal \\ ${ }^{\mathrm{b}}$ Interdisciplinary Center of Marine and Environmental Research-CIMAR/CIIMAR, University of Porto, Novo Edifício do Terminal de Cruzeiros do Porto de Leixões, \\ Avenida General Norton de Matos, 4450-208 S/N Matosinhos, Portugal \\ ${ }^{c}$ Laboratorio CIFGA S.A., Avda. Benigno Rivera no. 56, 27003 Lugo, Spain \\ ${ }^{\mathrm{d}}$ Department of Pharmacology, Faculty of Veterinary, University of Santiago of Compostela, 27002 Lugo, Spain \\ ${ }^{\mathrm{e}}$ University of Madeira, Faculty of Life Sciences, Marine Biology Station of Funchal, 9000-107 Funchal, Portugal \\ ${ }^{\mathrm{f}}$ Center of Interdisciplinary Marine and Environmental Research of Madeira-CIIMAR-Madeira, Edif. Madeira Tecnopolo, Caminho da Penteada, 9020-105 Funchal, \\ Portugal \\ ${ }^{\mathrm{g}}$ cE3c/GBA-Centre for Ecology, Evolution and Environmental Changes/Azorean Biodiversity Group, Department of Biology, Faculty of Sciences and Technology, \\ University of Azores, 9501-801 Ponta Delgada, São Miguel, Azores, Portugal \\ ${ }^{\mathrm{h}}$ Phycology Research Unit-Biotechnology, Ecosystems Ecology and Valorization Laboratory, Faculty of Sciences El Jadida, University Chouaib Doukkali, BP20 El Jadida, \\ Morocco
}

\section{A R T I C L E I N F O}

\section{Keywords:}

Azaspiracids

Pectenotoxins

Yessotoxins

Spirolides

New vectors

North Atlantic

\begin{abstract}
A B S T R A C T
In the last decades, due to monitoring programs and strict legislation poisoning incidents occurrence provoked by ingestion of naturally contaminated marine organisms has decreased. However, climate change and anthropogenic interference contributed to the expansion and establishment of toxic alien species to more temperate ecosystems. In this work, the coasts of Madeira, São Miguel islands and the northwestern Moroccan coast were surveyed for four groups of lipophilic toxins (yessotoxins, azaspiracids, pectenotoxins, and spirolides), searching for new vectors and geographical tendencies. Twenty-four species benthic organisms were screened using UHPLC-MS/MS technique. We report 19 new vectors for these toxins, six of them with commercial interest ( $P$. aspera, $P$. ordinaria, C. lampas, $P$. pollicipes, $H$. tuberculata and $P$. lividus). Regarding toxin uptake a south-north gradient was detected. This study contributes to the update of monitoring routines and legislation policies, comprising a wider range of vectors, to better serve consumers and ecosystems preservation.
\end{abstract}

\section{Introduction}

Harmful Algal Blooms (HABs), are dense clouds of algae with erratic nature whose forming circumstances are still to disclosure. HABs can vary in species composition (mono or polyspecific), occurrence and frequency (Hallegraeff, 1993; Smayda, 1997). Consequences of global changing together with anthropogenic intervention such as the rising of water temperature and ecosystems eutrophication derived from the anthropogenic intervention are pointed as significative factors for the increase in frequency, persistence, and intensity of these blooms in the past decades (Hallegraeff, 2010; Heisler et al., 2008). So far, about 300 marine phytoplankton species have been reported as bloom-forming, being 40 of them pointed as toxic, noxious or nuisance (Moore et al., 2008; Smayda, 1997). HABs adverse consequences are not measured by cell abundance but by the magnitude of their impact, they can affect an entire ecosystem in different ways by causing high mortalities in wildlife (Conley et al., 2009; Yang and Albright, 1992), affecting economy, namely the fishery and touristic sectors (Hoagland and

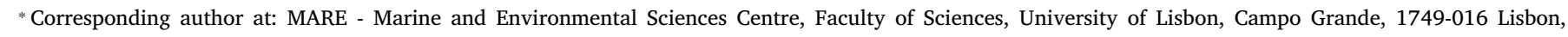
Portugal.

E-mail addresses: mpdsilva@fc.ul.pt (M. Silva), ines.rodriguez@cifga.com (I. Rodríguez), mkaufmann@ciimar.up.pt (M. Kaufmann), ana.im.neto@uac.pt (A.I. Neto), sabour.b@ucd.ac.ma (B. Sabour), amparo.alfonso@usc.es (A. Alfonso), Luis.Botana@usc.es (L.M. Botana), vmvascon@fc.up.pt (V. Vasconcelos).

${ }^{1}$ These authors contributed equally to this work. 
Scatasta, 2006; Morgan et al., 2009), and by inducing human poisoning incidents. Human toxin exposure can occur through via many routes, being the most common by ingestion of contaminated seafood, although there are reports of poisoning incidents provoked by dermal contact and inhalation of aerosolized forms (Backer et al., 2005; Cheng et al., 2005; Fleming et al., 2005; Fleming et al., 2001). Due to market demand, FAO's report on "The State of World Fisheries and Aquaculture", states that global aquaculture had a severe increase since the 1950 s, forecasting that this trend will continue with a $3.6 \%$ of growth rate every year (Etheridge, 2010). This market globalization, international fish trade increased the need for guidelines, monitoring procedures and the development of reliable detection methods to provide and ensure safety to consumers (Alam et al., 1978; Silva et al., 2013; Takahashi et al., 2001; Yotsu-Yamashita et al., 2001). Since, marine biotoxins are secondary metabolites with phytoplankton and bacterial origin, whose primary goal is to enhance survival strategies to their producers against competitors and predators, yet in this context, human poisoning incidents are an indirect consequence of this surviving strategy (Cembella, 2003; Hallegraeff, 2010). Almost 200 different compounds have been described, divided into 12 different groups (FAO/IOC/WHO, 2004), however, only half of them have a regulatory status: azaspiracids (AZAs), domoic acid group (DA), okadaic acid and dinophysistoxins group (DSPs), saxitoxins (STXs) and recently tetrodotoxin group (TTXs) in the Netherlands (Alexander et al., 2008a, 2009a; Alexander et al., 2009b; Alexander et al., 2008c; Gerssen et al., 2018). Nowadays, in the European Union (EU) and Morocco, the regulated marine toxins are lipophilic toxins, paralytic shellfish toxins and amnesic shellfish toxins. Regarding monitoring programs, liquid chromatography coupled to tandem mass spectrometry (LC-MS/MS) is used in the EU as reference method (European Union Refenrence Laboratory for Marine Biotoxins, 2013; European Union Reference Laboratory for Marine Biotoxins, 2015). The current EU regulatory limit for marine lipophilic toxins in shellfish meat (SM) are for DSPs $160 \mu \mathrm{g}$ OA equivalents/kg SM; AZAs $160 \mu \mathrm{g}$ AZA equivalents/kg SM; PTXs $160 \mu \mathrm{g}$ OA equivalents/kg SM (combination of OA, DTXs and PTXs); and finally, for YTXs $3.75 \mathrm{mg}$ YTX/kg SM (Alam et al., 1978; Silva et al., 2013).

Marine lipophilic toxins are categorized into different groups, which are characterized by different chemical structures and different mechanisms of toxicity. These groups can be produced by the same or by different species of marine microalgae. In this work, we studied the occurrence of these four groups of lipophilic toxins in three different locations (Fig. 1).

Toxins belonging to the YTX group are cytotoxic polyethers (Fig. 1) first isolated in 1986 in Japan, from the digestive gland of the scallop Mizuhopecten yessoensis (Bianchi et al., 2004; Konishi et al., 2004; Murata et al., 1987; Pérez-Gómez et al., 2006). Concerning their origin, dinoflagellate species of Gonyaulax spinifera, Protoceratium reticulatum, and Lingulodinium polyedrum are pointed as main producers (Eiki et al., 2005; Paz et al., 2004; Rhodes et al., 2006). Initially, YTXs were included in the DSP group, due to their lipophilic features. The DSPs characteristic intoxication symptoms are diarrhea through inhibition of phosphatases (Bialojan and Takai, 1988). Since YTXs were not shown to provoke these symptoms, the European Food Safety Authority (EFSA) proposed the guideline for YTXs (Alexander et al., 2008b; Bianchi et al., 2004; Konishi et al., 2004; Ogino et al., 1997; Pérez-Gómez et al., 2006; Tubaro et al., 2011). These heat-stable polyethers were detected mainly in bivalve species (scallops and mussels) from Japan, Italy, Spain, United Kingdom, Norway, Russia, Canada, Chile and New Zealand (Ciminiello et al., 1997; Lee et al., 1988; Murata et al., 1987; Stobo et al., 2003; Vershinin et al., 2006; Yasumoto and Takizawa, 1997). With up to 90 analogs described so far, only 30 were fully characterized, being the most relevant: 45-hydroxyYTX, 45-hydroxy-1ahomoYTX, and 1a-homoYTX (Alexander et al., 2008b).

AZAs are lipophilic phycotoxins with three spiro bonds between rings (Fig. 1). The first AZA isolated was AZA-1 in 1995 following a toxic episode in the Netherlands due to contaminated mussels (McMahon and Silke, 1996). The symptoms of AZA poisoning are nausea, vomiting, diarrhea and stomach cramps. These toxins were detected in several species of filter-feeding mollusks (oysters, mussels, scallops, and clams) (Hess et al., 2003; McMahon and Silke, 1996). Also, one of the main AZA producers are dinoflagellates, such as $A z a-$ dinium spinosum and Azadinium poporum (Krock et al., 2008, 2009; Krock et al., 2019; Tillmann et al., 2009). EFSA established the toxic equivalent factors (TEFs) for this group 1 for AZA-1, 1.8 for AZA-2 and 1.4 for AZA-3 (Alexander et al., 2008c).

PTXs are macrocyclic polyethers, unstable in strongly basic conditions and to date 15 different analogs have been isolated (Fig. 1) (Suzuki, 2008). Under EU legislation these toxins were included within the DSP group because they were produced by Dinophysis spp. Nowadays, PTXs are considered an independent group since their absence of recorded symptomatology, neither poisoning incidents recorded (European Food Safety Authority, 2009). However, several studies have confirmed that chronical exposure to this group of toxins causes alterations of the actin-based cytoskeleton (Espina et al., 2008). Being the toxicological database of this group is limited and no reports on adverse effects in humans so far, EFSA established provisional TEFs value of 1 for PTX-1, PTX-2, PTX-3, PTX-4, PTX-6 and PTX-11 (European Food Safety Authority, 2009).

Cyclic imines (CIs) are a heterogenic group of macrocyclic compounds having imine and ester groups and spiro unions (Fig. 1) (European Food Safety Authority, 2010; Molgó et al., 2014). The SPXs are neurotoxic and their target is nicotinic and muscarinic acetylcholine receptors (mAChR and nAChR, respectively) in the central and peripheral nervous system and at the neuromuscular junction (Meilert and Brimble, 2006; Molgó et al., 2014). These toxins were discovered in the 90s during a routine monitorization in Canada and New Zealand, but in subsequent years CIs have been also detected in European waters (Amzil et al., 2007; Hu et al., 1995; Seki et al., 1995; Villar Gonzalez et al., 2006). Currently, regulations regarding SPXs in the EU are absent, only a recommended guidance level of $400 \mu \mathrm{g}$ total SPXs $/ \mathrm{kg}$, due to the lack of reports regarding their acute toxicity, though their effects regarding chronical exposure are still to be unravel (European Food Safety Authority, 2010; Otero et al., 2011a). Several detection methods have been developed for this group of compounds like mouse bioassay (MBA), biochemistry assays, LC-MS/MS methods, etc. (Bourne et al., 2010; Gerssen et al., 2009; Marrouchi et al., 2010; Otero et al., 2011b; Yasumoto et al., 1978). Taking into account that these toxins are lipophilic, and they can be extracted with the regulated lipophilic toxins method, they are suited to be included in EU Reference Laboratory for Marine Biotoxins (EU-RL-MB) detection method (European Union Reference Laboratory for Marine Biotoxins, 2015).

In this work, the Portuguese Islands of Madeira and S. Miguel, and the northwestern Moroccan coast were surveyed for four groups of lipophilic toxins. As mentioned above, the rise of water temperature, derived from global change, together with anthropologic inputs, aided the migration and establishment of these phycotoxins from warm ecosystems to more temperate ones. EFSA defined "emergent toxins" as recently discovered nonregulated toxins or reported toxins previously absent (Alexander et al., 2010; Reverté et al., 2014). In this context, these toxins (AZAs, YTXs and PTXs) can be considered emergent toxins in Madeira and Azores despite being regulated they are not common in these areas. On the other hand, SPXs fall into the category of emerging toxins, since they are not regulated or reported in the screened areas monitored in this work. Considering this premises, our primal aim was to search for new non-traditional vectors, unravel geographical tendencies to assess human health risk. In this context, the DSP group was not described in this work because the results obtained for this group were presented in a previous paper (Silva et al., 2015b). 


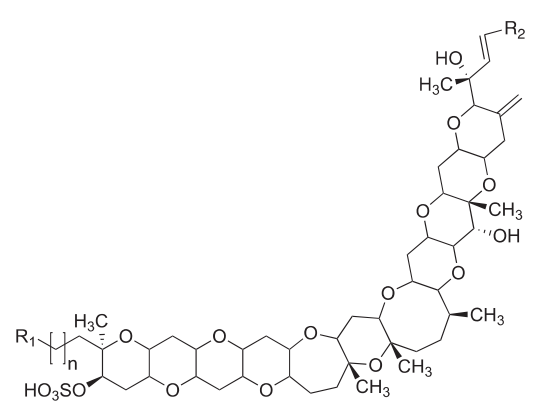

YTXs

\begin{tabular}{|c|c|c|c|}
\hline Toxin & $\mathrm{n}$ & R1 & R2 \\
\hline YTX & 1 & $\mathrm{OSO}_{3} \mathrm{Na}$ & \\
\hline OH-YTX & 1 & $\mathrm{OSO}_{3} \mathrm{Na}$ & \\
\hline HomoYTX & 2 & $\mathrm{OSO}_{3} \mathrm{Na}$ & \\
\hline OH-homoYTX & 2 & $\mathrm{OSO}_{3} \mathrm{Na}$ & 0 \\
\hline
\end{tabular}
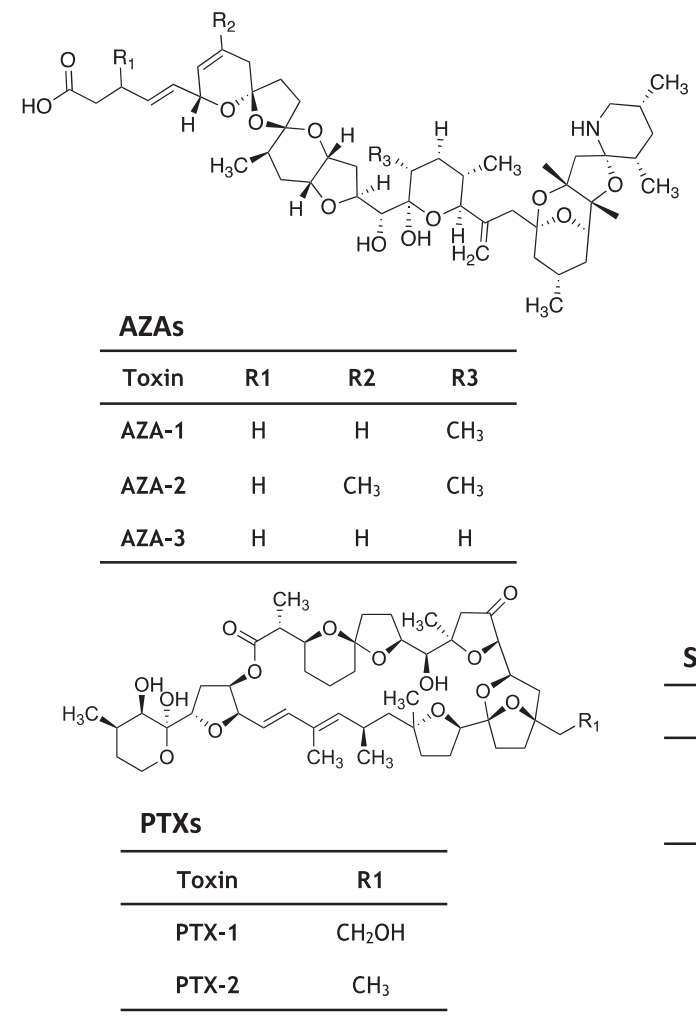

Fig. 1. Marine lipophilic toxins.

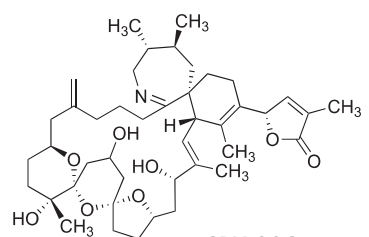

SPX-20G

\section{Materials and methods}

\subsection{Chemicals}

Acetonitrile, dichloromethane, and methanol were from Panreac (Barcelona, Spain). All solvents were analytical grade and water was obtained from a water purification system (Milli-Q, Millipore, Spain). Formic acid was purchased from Merck (Darmstadt, Germany). Ammonium formate was from Fluka (Sigma-Aldrich, Spain).

Certified reference materials provided by Cifga (Lugo, Spain) were: pectenotoxin-2 (PTX-2, $7.27 \pm 0.33 \mu \mathrm{g} / \mathrm{mL}$ ), yessotoxin (YTX $7.42 \pm 0.49 \mu \mathrm{g} / \mathrm{g}$ ), 1a-homoyessotoxin (homoYTX $7.68 \pm 0.44 \mu \mathrm{g}$ / g), azaspiracid-1 (AZA-1 $1.36 \pm 0.07 \mu \mathrm{g} / \mathrm{g}$ ), azaspiracid-2 (AZA-2 $1.33 \pm 0.11 \mu \mathrm{g} / \mathrm{g}$ ) and azaspiracid-3 (AZA-3 $1.30 \pm 0.09 \mu \mathrm{g} / \mathrm{g}$ ).

The quality control standard provided by Cifga (Lugo, Spain) was 20-methyl spirolide G (SPX-20G $7.01 \pm 0.61 \mu \mathrm{g} / \mathrm{mL})$.

\subsection{Sampling sites and selected species}

In the present study a total of 101 samples were collected, aiming to screen lipophilic toxins in different species of benthic organisms: from echinoderms (Astropecten aranciacus, Echinaster sepositus, Marthasterias glacialis, Ophidiaster ophidianus, Holothuria (Platyperona) sanctori, Arbacia lixula, Diadema africanum, Paracentrotus lividus, Sphaerechinus granularis), to arthropods (Pollicipes pollicipes) and mollusks (Mytilus spp., Phorcus lineatus, Haliotis tuberculata, Onchidella celtica, Pattela aspera, Patella spp., Umbraculum umbraculum, Stramonita haemostoma, Charonia lampas, Cerithium vulgatum, Gibbula umbilicalis, Aplysia depilans, Patella gomesii, Patella ordinaria). Samples were collected in the intertidal zone and by Self-Contained Underwater Breathing Apparatus (SCUBA) diving in three different locations (Fig. 4). Edible and nonedible species were selected due to their inherent economic relevance and by their key position in the food web (Table 1), since phycotoxin bioaccumulation phenomena already been reported in former work
(Silva et al., 2015b).

Sample expeditions were performed in three different geographical locations (Azores and Madeira archipelagos (Portugal) and the northwestern Moroccan coast), between September 2012 and July 2013 (Fig. 2). Samples of $P$. ordinaria and $P$. aspera were purchased in local markets in Madeira, caught on the northern coast of the island $\left(32^{\circ} 51^{\prime} 17.02^{\prime \prime} \mathrm{N} ; 17^{\circ} 01^{\prime} 54.02^{\prime \prime} \mathrm{W}\right)$. After harvesting, samples were transported to the laboratory in refrigerated containers. If immediate processing was not possible, samples were stored at $-20{ }^{\circ} \mathrm{C}$.

\subsection{Sample extraction}

Samples were extracted following the extraction procedure (Otero et al., 2010; Silva et al., 2015b). The animals were homogenized with a blender (A320R1, 700 W, Moulinex, Lisbon, Portugal), previously the shells were removed when necessary. In some cases, the animals were homogenized in pooled groups in order to obtain $1 \mathrm{~g}$ of tissue. In the case of $O$. ophidianus, $P$. lividus, $S$. granularis, $U$. umbraculum, $D$. africanum, $H$. sanctori, C. lampas, $M$. glacialis, and A. depilans each animal was handled separately since it had enough biomass. Then, $1 \mathrm{~g}$ of homogenized tissue was weighed into a centrifuge tube and $3 \mathrm{~mL}$ of methanol was added. The sample was homogenized via vortex mixing at maximum speed level. Afterward, the extracts were centrifuged for $10 \mathrm{~min}$ at $2932 \mathrm{~g}$ at $4{ }^{\circ} \mathrm{C}$ and the supernatant was transferred to a $15 \mathrm{~mL}$ volumetric flask. The extraction was repeated twice, the supernatants were combined and concentrated to dryness. Next, residues were resuspended in $10 \mathrm{~mL}$ of Milli-Q water and liquid-liquid extraction with dichloromethane was done. The aqueous layer was extracted again with $10 \mathrm{~mL}$ of dichloromethane and the organic layers $(20 \mathrm{~mL}$ of final volume) were concentrated to dryness and re-suspended in $200 \mu \mathrm{L}$ of methanol. The determination of PTXs, AZAs, YTXs, and SPXs was performed by ultra-high liquid chromatography coupled to tandem mass spectrometry (UHPLC-MS/MS) after filtering a methanolic extract aliquot with $0.22 \mu \mathrm{m}$ filter (UltraFree-MC centrifugal devices, Millipore). 
Table 1

Sampled species description.

\begin{tabular}{|c|c|c|c|c|c|c|c|}
\hline Species & Sample type & Trophic level & Sampling site(s) & AN & Ed & MS & Ref \\
\hline A. aranciacus & Echinodermata asteroidea & 2nd level predator & Madeira & 2 & No & No & (Burla et al., 1972) \\
\hline A. depilans & Mollusca gastropoda & Grazer & Morocco & 1 & No & No & (Carefoot, 1987) \\
\hline A. lixula & Echinodermata echinoidea & Grazer & Madeira/Azores/Morocco & 4 & No & No & (Bulleri et al., 1999) \\
\hline C. lampas & Mollusca gastropoda & 3rd level predator & Madeira/Morocco & 1 & Yes & No & (Lin and Hwang, 2001) \\
\hline C. vulgatum & Mollusca gastropoda & Grazer & Morocco & 40 & Yes & No & (Nicolaidou and Nott, 1999) \\
\hline D. africanum & Echinodermata echinoidea & Grazer & Madeira & 1 & No & No & (Rodríguez et al., 2013) \\
\hline E. sepositus & Echinodermata asteroidea & 2nd level predator & Madeira & 3 & No & No & (Ferguson, 1969) \\
\hline G. umbilicalis & Mollusca gastropoda & Grazer & Morocco & 100 & Yes & No & (Crothers, 2001) \\
\hline H. sanctori & Echinodermata holothuroidea & Deposit feeder & Morocco & 1 & Yes & No & (Navarro et al., 2013; Toral-Granda et al., 2008) \\
\hline M. glacialis & Echinodermata asteroidea & 2nd level predator & Madeira/Azores/Morocco & 1 & No & No & (Knox, 2001) \\
\hline P. lineatus & Mollusca gastropoda & Grazer & Morocco & 86 & Yes & No & (Crothers, 2001) \\
\hline Mytilus spp. & Mollusca bivalvia & Filter feeder & Morocco & 30 & Yes & Yes & (Buschbaum et al., 2008) \\
\hline O. celtica & Mollusca gastropoda & Grazer & Morocco & 50 & No & No & (Dayrat, 2009) \\
\hline O. ophidianus & Echinodermata asteroidea & Detritivorous & Madeira/Azores & 1 & No & No & (Ferguson, 1969) \\
\hline P. aspera & Mollusca gastropoda & Grazer & Madeira & 15 & Yes & No & (Knox, 2001) \\
\hline Patella spp. & Mollusca gastropoda & Grazer & Morocco & 12 & Yes & No & (Knox, 2001) \\
\hline P. gomesii & Mollusca gastropoda & Grazer & Azores & 10 & Yes & No & (Knox, 2001) \\
\hline P. lividus & Echinodermata echinoidea & Grazer & Madeira/Azores/Morocco & 1 & Yes & No & (Lemée et al., 1995) \\
\hline P. pollicipes & Arthropoda hexanauplia & Filter feeder & Morocco & 35 & Yes & No & (Knox, 2001) \\
\hline S. granularis & Echinodermata echinoidea & Grazer & Azores & 1 & Yes & No & (Martinez-Pita et al., 2008) \\
\hline U. umbraculum & Mollusca gastropoda & Grazer & Madeira & 1 & No & No & (Valdes, 2001) \\
\hline S. haemostoma & Mollusca gastropoda & 2nd level predator & Madeira/Azores/Morocco & 15 & No & No & (Ramírez et al., 2009) \\
\hline H. tuberculata & Mollusca gastropoda & Grazer & Azores & 1 & Yes & No & (Peck, 1989) \\
\hline P. ordinaria & Mollusca gastropoda & Grazer & Madeira & 10 & Yes & No & (Faria et al., 2017) \\
\hline
\end{tabular}

AN: average number of organisms to compose a sample; Ed: edible; MS: monitoring status; Ref: references.

A
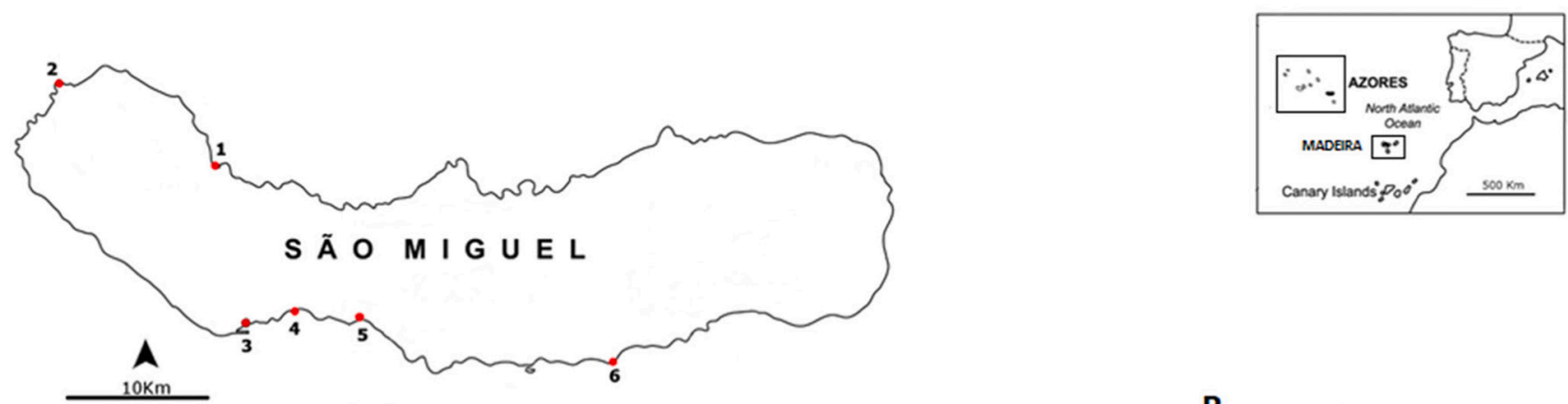

C

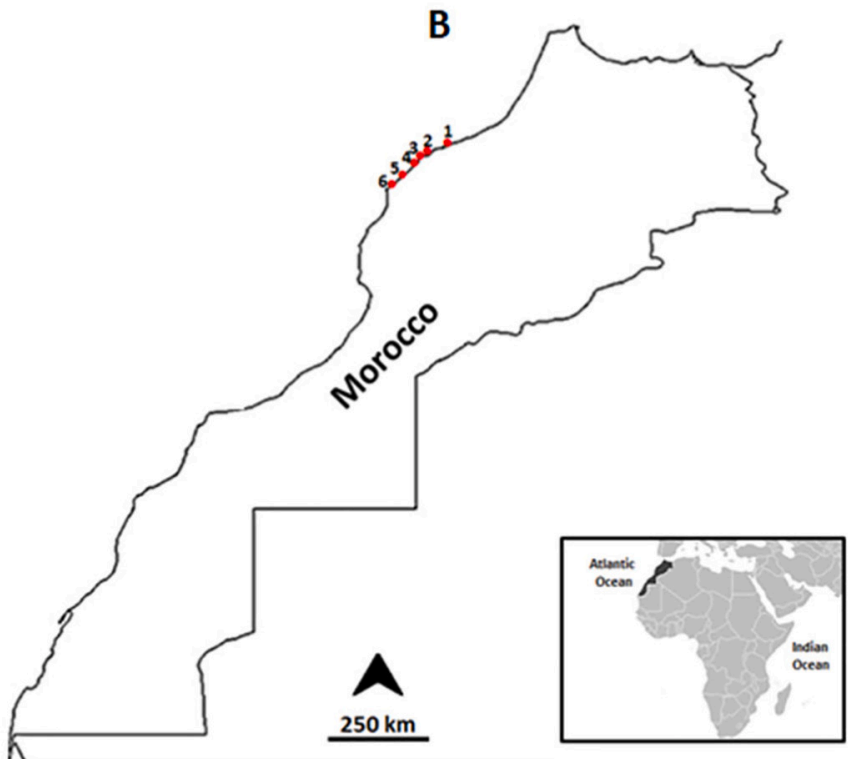

Fig. 2. Location of the sampling sites: (A) São Miguel island coast, Azores archipelago: 1, Cruzeiro; 2, Mosteiros; 3, Étar; 4, São Roque; 5, Lagoa; 6, Caloura. (B) Northwestern Moroccan coast: 1, Casablanca Corniche; 2, El Jadida Haras; 3, El Jadida Sâada; 4, Sidi Bouzid; 5, Mrizika; 6, Oualidia (C) Madeira island coast: 1, Reis Magos and 2, Caniçal. 


\subsection{UHPLC-MS/MS method}

The UHPLC-MS/MS analysis was performed by a 1290 Infinity ultrahigh-performance liquid chromatography system coupled to a 6460 Triple Quadrupole mass spectrometer (Agilent Technologies, Waldbronn, Germany). The nitrogen generator was a Nitrocraft NCLC/ MC from Air Liquid (Spain).

The toxins were separated using a column ACQUITY UPLC BEH C18 $\left(2.1 \times 100 \mathrm{~mm}, 1.7 \mu \mathrm{m}\right.$, Waters) at $40{ }^{\circ} \mathrm{C}$. Mobile phase A was composed of $100 \%$ water and B by acetonitrile-water (95:5), both containing $50 \mathrm{mM}$ formic acid and $2 \mathrm{mM}$ ammonium formate. The gradient elution (6.5 min) was: starting with $30 \% \mathrm{~B}$, then $30-70 \%$ B for 3 min, then, $70 \%$ B was held for $1.5 \mathrm{~min}$ and reducing afterward to $30 \%$ B over $0.1 \mathrm{~min}$ and hold for $1.99 \mathrm{~min}$ until the next run. The samples in the autosampler were cooled to $4{ }^{\circ} \mathrm{C}$ and injection volume was $5 \mu \mathrm{L}$.

MS detection was performed using an Agilent G6460C triple quadrupole mass spectrometer equipped with an Agilent Jet Stream ESI source (Agilent Technologies, Waldbronn, Germany). Source conditions were optimized to achieve the best sensitivity for all compounds. A drying gas temperature of $350{ }^{\circ} \mathrm{C}$ and a flow of $8 \mathrm{~L} / \mathrm{min}$. A nebulizer gas pressure of $45 \mathrm{psi}$. A sheath gas temperature of $400{ }^{\circ} \mathrm{C}$ and a flow of $11 \mathrm{l} / \mathrm{min}$. The capillary voltage was set to $4000 \mathrm{~V}$ in negative mode with a nozzle voltage of $0 \mathrm{~V}$ and $3500 \mathrm{~V}$ in positive mode with a nozzle voltage of $500 \mathrm{~V}$. The analysis was carried out using electrospray ionization (ESI) and multiple reaction monitoring (MRM) acquisition in positive and negative mode. The collision energy, cell accelerator voltage, and fragmentor were optimized using MassHunter Optimizer software. Two product ions were analyzed per compound, one for quantification and another for confirmation (Table 2).

\subsection{Statistical analyses}

Patterns of toxin distribution across geographical regions and organisms were explored with the multivariate technique Principal Components Analysis (PCA). For this analysis, data on less frequent toxins in the data set, with $\sim 1$ positive sample were removed, and analogous molecules were grouped into a single class for YTXs and AZAs. PCA was performed with PCA function from the FactoMineR $R$ package (Lê et al., 2008).

\section{Results}

In this study, a total of 24 species were collected, from three different locations along the North Atlantic in August and September 2012, and June and July 2013.

In Madeira Island a total of 25 samples were harvested, 37 samples in São Miguel Island (Azores) and 39 samples along the north-western coast of Morocco, for the identify and quantify lipophilic toxins using UHPLC-MS/MS technique in MRM mode.

Each toxin group was quantified by means of several certified reference materials: AZA-1, 2 and 3; YTX and homoYTX; SPX-20G; and PTX-2 (Fig. 3).

Nine-point calibration curves ranging between $(20 \mu \mathrm{g} / \mathrm{kg}$ and $0.08 \mu \mathrm{g} / \mathrm{kg}$ ) were used for the quantification of AZA-1-3; SPX-20G; and PTX-2. To quantify the YTX group, calibration curves ranged between ( $50 \mu \mathrm{g} / \mathrm{kg}$ and $0.2 \mu \mathrm{g} / \mathrm{kg}$ ). Limit of detection (LOD) and the limit of quantification (LOQ) were determined for each toxin (Table 3 ).

\subsection{Madeira Island}

A total of 25 samples were collected in August and September 2012. Lipophilic toxins were detected in 24 samples, 7 mollusks and 17 echinoderms and the average concentrations detected were below the legal limit in the EU (Table 3). PXT-2 was detected only in one sample of E. sepositus (353) among the total screened samples. For AZAs, a total of 24 from 25 analyzed samples were positive in AZA-2 and the highest concentration sample for this toxin was $O$. ophidianus (341\#1), $53.16 \mu \mathrm{g} / \mathrm{kg}$. In the case of AZA- 1 and AZA-3, a total of $64 \%$ and $60 \%$ of the samples presented these toxins, respectively, from a total of 25 samples. For AZA-1, the detected concentrations ranged from $0.41 \mu \mathrm{g} /$ $\mathrm{kg}$ in P. ordinaria (336) to $6.15 \mu \mathrm{g} / \mathrm{kg}$ in O. ophidianus (341\#1) and $87 \%$ of positive samples were echinoderms from a total of 16 positive samples. Finally, for AZA-3, concentration ranged from $0.31 \mu \mathrm{g} / \mathrm{kg}$ in $P$. lividus (339\#1 and 339\#2) to $2.08 \mu \mathrm{g} / \mathrm{kg}$ in O. ophidianus (341\#1) and in this case echinoderms represented $93 \%$ of positive samples. Regarding CIs, for SPX-13, a total of $80 \%$ of samples contained this toxin, but only two were above the LOQ; O. ophidianus (341\#1) and E. sepositus (353) with $2.49 \mu \mathrm{g} / \mathrm{kg}$ and $0.24 \mu \mathrm{g} / \mathrm{kg}$, respectively.

Table 2

The main characteristic of UHPLC-MS/MS method in MRM mode for lipophilic toxins.

\begin{tabular}{|c|c|c|c|c|c|c|c|c|}
\hline Compound & Precursor ion & Product ions & $\mathrm{CE}$ & CAV & Frag & Polarity & LOD & LOQ \\
\hline \multirow[t]{2}{*}{ 45-OH-homoYTX } & 1171.5 & 869.5 & 88 & 250 & 4 & Negative & & \\
\hline & & 1091.5 & 40 & & & & & \\
\hline \multirow[t]{2}{*}{ 45-ОН-ҮTХ } & 1157.5 & 871.5 & 86 & 240 & 4 & Negative & & \\
\hline & & 1077.5 & 38 & & & & & \\
\hline \multirow[t]{2}{*}{ homoYTX } & 1155.5 & 869.4 & 88 & 250 & 4 & Negative & 0.23 & 0.78 \\
\hline & & 1075.5 & 40 & & & & & \\
\hline \multirow[t]{2}{*}{ YTX } & 1141.5 & 855.4 & 86 & 240 & 4 & Negative & 0.23 & 0.78 \\
\hline & & 1061.5 & 38 & & & & & \\
\hline \multirow[t]{2}{*}{ PTX-1 } & 892.5 & 213.2 & 44 & 175 & 2 & Positive & & \\
\hline & & 821.5 & 28 & & & & & \\
\hline \multirow[t]{2}{*}{ PTX-2 } & 876.5 & 213.2 & 44 & 175 & 2 & Positive & 0.09 & 0.31 \\
\hline & & 823.5 & 28 & & & & & \\
\hline \multirow[t]{2}{*}{ AZA-1 } & 842.5 & 806.5 & 44 & 206 & 4 & Positive & 0.02 & 0.08 \\
\hline & & 824.5 & 32 & & & & & \\
\hline \multirow[t]{2}{*}{ AZA-2 } & 856.5 & 820.5 & 44 & 213 & 2 & Positive & 0.02 & 0.08 \\
\hline & & 838.5 & 36 & & & & & \\
\hline \multirow[t]{2}{*}{ AZA-3 } & 828.5 & 792.5 & 44 & 216 & 4 & Positive & 0.02 & 0.08 \\
\hline & & 810.5 & 32 & & & & & \\
\hline \multirow[t]{2}{*}{ SPX-13 } & 692.5 & 164.2 & 60 & 75 & 4 & Positive & & \\
\hline & & 674.3 & 36 & & & & & \\
\hline \multirow[t]{2}{*}{ SPX-13,19 } & 678.5 & 164.2 & 60 & 260 & 4 & Positive & & \\
\hline & & 660.2 & 36 & & & & & \\
\hline \multirow[t]{2}{*}{ SPX-20G } & 706.5 & 164.2 & 56 & 233 & 4 & Positive & 0.02 & 0.08 \\
\hline & & 688.2 & 32 & & & & & \\
\hline
\end{tabular}

CE: collision energy (V); CAV: cell accelerator voltage (V); Frag: fragmentor; LOD: limit of detection ( $\mu \mathrm{g} / \mathrm{kg})$; LOQ: limit of quantification ( $\mu \mathrm{g} / \mathrm{kg})$. 
Table 3

Sample information from Madeira Island. Lipophilic toxins analyzed by LC-MS/MS in MRM mode.

\begin{tabular}{|c|c|c|c|c|c|c|c|}
\hline Sample type & Species & Code & PTX-2 $(\mu \mathrm{g} / \mathrm{kg})$ & AZA-1 $(\mu \mathrm{g} / \mathrm{kg})$ & AZA-2 $(\mu \mathrm{g} / \mathrm{kg})$ & AZA-3 $(\mu \mathrm{g} / \mathrm{kg})$ & SPX-13 $(\mu \mathrm{g} / \mathrm{kg})$ \\
\hline \multirow[t]{7}{*}{ Mollusca gastropoda } & P. ordinaria & 336 & & 0.41 & 1.23 & & $<$ LOQ \\
\hline & P. aspera & 337 & & & 0.16 & & $<$ LOQ \\
\hline & P. aspera & 344 & & & 0.33 & & $<\mathrm{LOQ}$ \\
\hline & S. haemastoma & 346 & & 0.85 & 2.35 & & $<$ LOQ \\
\hline & P. aspera & 350 & & & 1.44 & & $<$ LOQ \\
\hline & U. umbraculum & 351 & & & 1.25 & & $<\mathrm{LOQ}$ \\
\hline & C. lampas & 354 & & 1.62 & 14.75 & 1.04 & \\
\hline \multirow[t]{11}{*}{ Echinodermata echonoidea } & P. lividus & $339 \# 2$ & & & 1.25 & 0.31 & $<\mathrm{LOQ}$ \\
\hline & P. lividus & $339 \# 3$ & & & 1.21 & 0.31 & $<$ LOQ \\
\hline & P. lividus & $339 \# 4$ & & 1.53 & 7.85 & 1.35 & $<$ LOQ \\
\hline & A. lixula & 345 & & & 0.40 & 0.33 & $<\mathrm{LOQ}$ \\
\hline & A. lixula & 347 & & 0.81 & 3.67 & 0.37 & \\
\hline & P. lividus & $348 \# 1$ & & 0.90 & 5.03 & 0.76 & $<\mathrm{LOQ}$ \\
\hline & P. lividus & $348 \# 2$ & & 0.98 & 5.54 & 0.89 & $<\mathrm{LOQ}$ \\
\hline & P. lividus & $348 \# 4$ & & 0.88 & 4.92 & 0.77 & $<\mathrm{LOQ}$ \\
\hline & S. granularis & 349 & & 1.18 & 5.89 & 0.97 & \\
\hline & D. africanum & $355 \# 1$ & & 0.97 & 0.87 & & $<\mathrm{LOQ}$ \\
\hline & D. africanum & $355 \# 2$ & & & 0.20 & & \\
\hline \multirow[t]{6}{*}{ Echinodermata asteroidea } & A. aranciacus & 340 & & 1.67 & 7.80 & 1.08 & $<\mathrm{LOQ}$ \\
\hline & O. ophidianus & $341 \# 1$ & & 6.15 & 53.16 & 2.08 & 2.49 \\
\hline & O. ophidianus & $341 \# 2$ & & 2.31 & 22.98 & 0.98 & $<$ LOQ \\
\hline & O. ophidianus & $341 \# 3$ & & 2.04 & 20.13 & 1.39 & $<$ LOQ \\
\hline & M. glacialis & 342 & & 0.78 & 1.51 & & $<$ LOQ \\
\hline & E. sepositus & 353 & 5.91 & 1.05 & 6.64 & 1.11 & 0.24 \\
\hline
\end{tabular}

lividus, A. aranciacus, O. ophidianus, M. glacialis, A. lixula, S. granularis, E. sepositus, D. africanum). Fig. 4B, represents the percentage of each toxin per location. The AZA-2 was presented a high amount in São Miguel and Madeira islands considering the other lipophilic toxins analyzed in these samples being Madeira much more accused. While in Morocco the amount of homo-YTX current in eight samples corresponds to almost 50\% of total toxin amount. In this location, YTXs are the most important group since the four YTX analogs were detected in two samples in significant quantities.
Concerning the screened species, we report $79 \%$ of positive hits for new vectors, in Fig. 5 is displayed toxin incidence distribution pattern multivariate analysis. Curiously, the detected latitudinal pattern of lipophilic toxins uptake is reversed in comparison to previous work for the hydrophilic group of STXs (Silva et al., 2018). In the present work, the percentage of positive results follows a south-north gradient: being the presence of screened toxins less expressive in the Moroccan coast (67\%) in comparison with the Azores and Madeira archipelagos (88\%

Table 4

Sample information from Azores archipelago. Lipophilic toxins analyzed by LC-MS/MS in MRM mode.

\begin{tabular}{|c|c|c|c|c|c|c|c|c|}
\hline Sample & Species & Code & $\begin{array}{l}\text { 45-OH-homoYTX } \\
(\mu \mathrm{g} / \mathrm{kg})\end{array}$ & $\begin{array}{l}\text { YTX } \\
(\mu \mathrm{g} / \mathrm{kg})\end{array}$ & $\begin{array}{l}\text { AZA-1 } \\
(\mu \mathrm{g} / \mathrm{kg})\end{array}$ & $\begin{array}{l}\text { AZA-2 } \\
(\mu \mathrm{g} / \mathrm{kg})\end{array}$ & $\begin{array}{l}\text { AZA-3 } \\
(\mu \mathrm{g} / \mathrm{kg})\end{array}$ & $\begin{array}{l}\text { SPX-13 } \\
(\mu g / k g)\end{array}$ \\
\hline \multirow[t]{12}{*}{ Echinodermata echinoidea } & S. granularis & 409\#1 & & & & 0.85 & & \\
\hline & S. granularis & $409 \# 2$ & & & & 0.77 & & \\
\hline & S. granularis & $409 \# 3$ & & & & 0.97 & & \\
\hline & S. granularis & $409 \# 4$ & & & 0.6 & 0.76 & & \\
\hline & S. granularis & $409 \# 5$ & & & & 0.98 & & \\
\hline & S. granularis & $425 \# 1$ & 12.96 & & 0.28 & 1.15 & 0.61 & \\
\hline & S. granularis & $425 \# 2$ & & & & 1.11 & & \\
\hline & S. granularis & $425 \# 3$ & & & & 1.12 & & \\
\hline & A. lixula & 423 & & & 0.56 & 0.67 & & \\
\hline & A. lixula & 429 & & & & 0.61 & & \\
\hline & A. lixula & 432 & & & & 0.56 & & \\
\hline & A. lixula & 442 & & & & 0.11 & & \\
\hline \multirow[t]{13}{*}{ Echinodermata asteroidea } & M. glacialis & 411\#1 & & & & 1.13 & & \\
\hline & M. glacialis & $411 \# 2$ & & & 0.29 & 0.12 & & \\
\hline & M. glacialis & $411 \# 3$ & & 3.51 & & 0.18 & & \\
\hline & O. ophidianus & 412 & & & 13.97 & 66.98 & 17.15 & \\
\hline & O. ophidianus & 424 & & & 18.75 & 124.91 & 19.38 & \\
\hline & M. glacialis & $426 \# 1$ & & & & 0.95 & 0.75 & \\
\hline & M. glacialis & $426 \# 2$ & & & & 1.33 & 0.78 & \\
\hline & M. glacialis & 428 & & & & 0.30 & & \\
\hline & M. glacialis & $433 \# 1$ & & & 0.38 & 1.25 & & \\
\hline & M. glacialis & $433 \# 2$ & & & 0.59 & 0.87 & & \\
\hline & O. ophidianus & 435 & & & 9.79 & 36.90 & 7.68 & $<$ LOQ \\
\hline & O. ophidianus & 440 & & & 13.54 & 42.65 & 11.75 & \\
\hline & M. glacialis & 441 & & & 0.25 & 0.69 & & \\
\hline \multirow[t]{6}{*}{ Mollusca gastropoda } & S. haemostoma & 413 & & & & 1.26 & & \\
\hline & C. lampas & 414 & & 28.63 & 0.98 & 2.08 & & \\
\hline & S. haemostoma & 431 & & & 1.07 & 0.86 & & \\
\hline & S. haemostoma & 434 & & & 0.35 & 1.34 & & \\
\hline & H. tuberculata & 437 & & & & 0.29 & & \\
\hline & S. haemostoma & 443 & & & 0.77 & 1.32 & & \\
\hline
\end{tabular}


Table 5

Sample information from Moroccan coast. Lipophilic toxins analyzed by LC-MS/MS in MRM mode.

\begin{tabular}{|c|c|c|c|c|c|c|c|c|c|c|}
\hline Sample & Species & Code & $\begin{array}{l}\text { 45-OH-YTX } \\
(\mu \mathrm{g} / \mathrm{kg})\end{array}$ & $\begin{array}{l}\text { 45-OH-homo YTX } \\
(\mu \mathrm{g} / \mathrm{kg})\end{array}$ & $\begin{array}{l}\text { YTX } \\
(\mu g / k g)\end{array}$ & $\begin{array}{l}\text { homo-YTX } \\
(\mu \mathrm{g} / \mathrm{kg})\end{array}$ & $\begin{array}{l}\text { AZA-1 } \\
(\mu \mathrm{g} / \mathrm{kg})\end{array}$ & $\begin{array}{l}\text { AZA-2 } \\
(\mu \mathrm{g} / \mathrm{kg})\end{array}$ & $\begin{array}{l}\text { AZA-3 } \\
(\mu \mathrm{g} / \mathrm{kg})\end{array}$ & $\begin{array}{l}\text { SPX-13 } \\
(\mu g / k g)\end{array}$ \\
\hline \multirow[t]{5}{*}{ Mollusca bivalvia } & Mytilus spp. & 447 & 9.45 & 28.72 & 5.11 & 29.93 & & 1.06 & & \\
\hline & Mytilus spp. & 453 & & 2.93 & & & 0.83 & 0.97 & & \\
\hline & Mytilus spp. & 465 & 2.88 & 8.48 & & 12.32 & & 0.08 & & \\
\hline & Mytilus spp. & 468 & & & & 3.06 & 0.29 & 1.36 & & \\
\hline & Mytilus spp. & 485 & & & & 1.41 & & 0.11 & & \\
\hline \multirow[t]{13}{*}{ Mollusca grastropoda } & $P$. lineatus & 448 & & & & 6.00 & & 0.91 & & \\
\hline & $P$. lineatus & 449 & & & & & & 0.95 & & \\
\hline & A. depilans & 451 & & & & & & 0.50 & & \\
\hline & C. vulgatum & 454 & & & & & & 0.45 & & \\
\hline & P. lineatus & 455 & & & 1.16 & & 0.65 & 0.14 & & \\
\hline & G. umbilicalis & 460 & & & & & & 0.82 & & \\
\hline & G. umbilicalis & 469 & & & & & & 0.19 & & \\
\hline & P. lineatus & 470 & & & & 8.19 & & 0.22 & & \\
\hline & C. lampas & 475 & & & & & 0.33 & 1.63 & 0.88 & \\
\hline & A. depilans & 476 & & & & & & 1.15 & & \\
\hline & S. haemostoma & 477 & 1.07 & 2.25 & 1.09 & 6.27 & & 0.73 & & \\
\hline & $P$. lineatus & 482 & & & & & 0.93 & 0.79 & & \\
\hline & G. umbilicalis & 483 & & & & & & 0.14 & & \\
\hline \multirow[t]{5}{*}{ Echinodermata echinoidea } & P. lividus & 452 & & & & & & 0.36 & & \\
\hline & P. lividus & $457 \# 1$ & & & & & & 0.14 & & \\
\hline & P. lividus & $457 \# 2$ & & & & & & 0.10 & & \\
\hline & P. lividus & 472 & & & & & & 0.82 & 0.24 & \\
\hline & P. lividus & 479 & & & & & & 0.98 & 0.28 & \\
\hline \multirow[t]{2}{*}{ Echinodermata asteroidea } & M. glacialis & 463 & & & & & & 1.17 & & \\
\hline & M. glacialis & 473 & 2.20 & & 2.73 & 9.15 & 0.34 & 2.78 & 0.66 & $<$ LOQ \\
\hline Arthropoda hexanauplia & P. pollicipes & 464 & & & & & & 0.83 & & \\
\hline
\end{tabular}

and $84 \%$ respectively). This could be due to the distribution of the main producers along the screened coasts, though more studies are needed to clarify this matter.

Moreover, the two principal components accounted for $75 \%$ of data variance, being the first component strongly positively correlated with the presence of AZAs and SPX-13, a signature of most samples from Azores and Madeira archipelagos. In fact, Kaufmann et al. (2015) reported the presence of Azadinium cf. dexteropor in the Madeira Island, corroborating our data in this sampling ground (Kaufmann et al., 2015). The second principal component is positively correlated with the presence of YTXs, which is mainly associated with samples from Morocco. In summary, the geographical patterns are the main explanation for the variance observed in toxin distribution and are defined by a differential toxin profile. Among organisms, there are no significant differences except for $O$. ophidianus, and to a lesser extent Mytilus spp. which tends to accumulate significantly more toxins than others. The reason for that outcome probably is due to the feeding habits of each organism and their trophic level, more studies are needed to clarify this matter.

Regarding consumer's preferences, the commercialization and demand for crustaceans, gastropods, and echinoderms have increased in the last years (FAO, 2015). Therefore, it is pertinent to adjust monitoring strategies and update legislation regarding limit values. Nevertheless, reference methods have been developed and optimized for bivalves, and it is proofed that monitoring based only on this group of

\section{A}
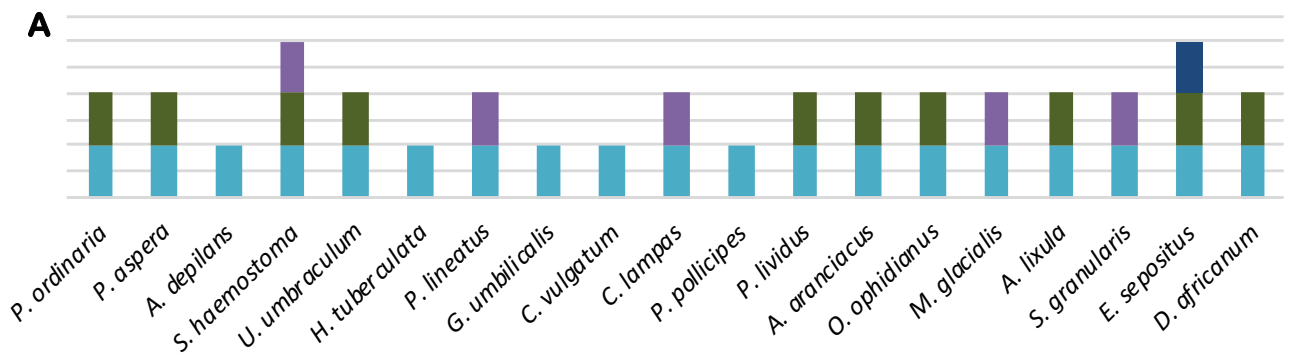

AZA $\square$ SPX $\square$ YTX $\square$ PTX

B

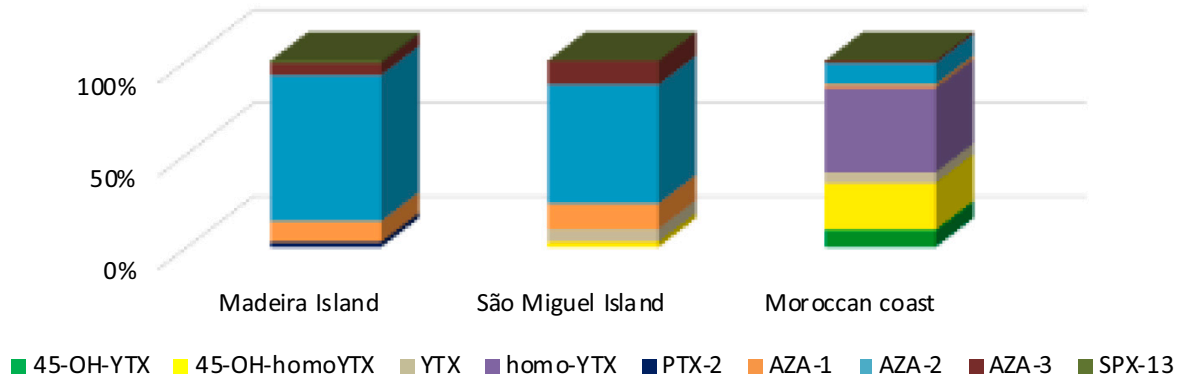

Fig. 4. A. Species identified as new vectors for each group of screened toxins. B. Percentage of each lipophilic toxin considering total toxin amount. 


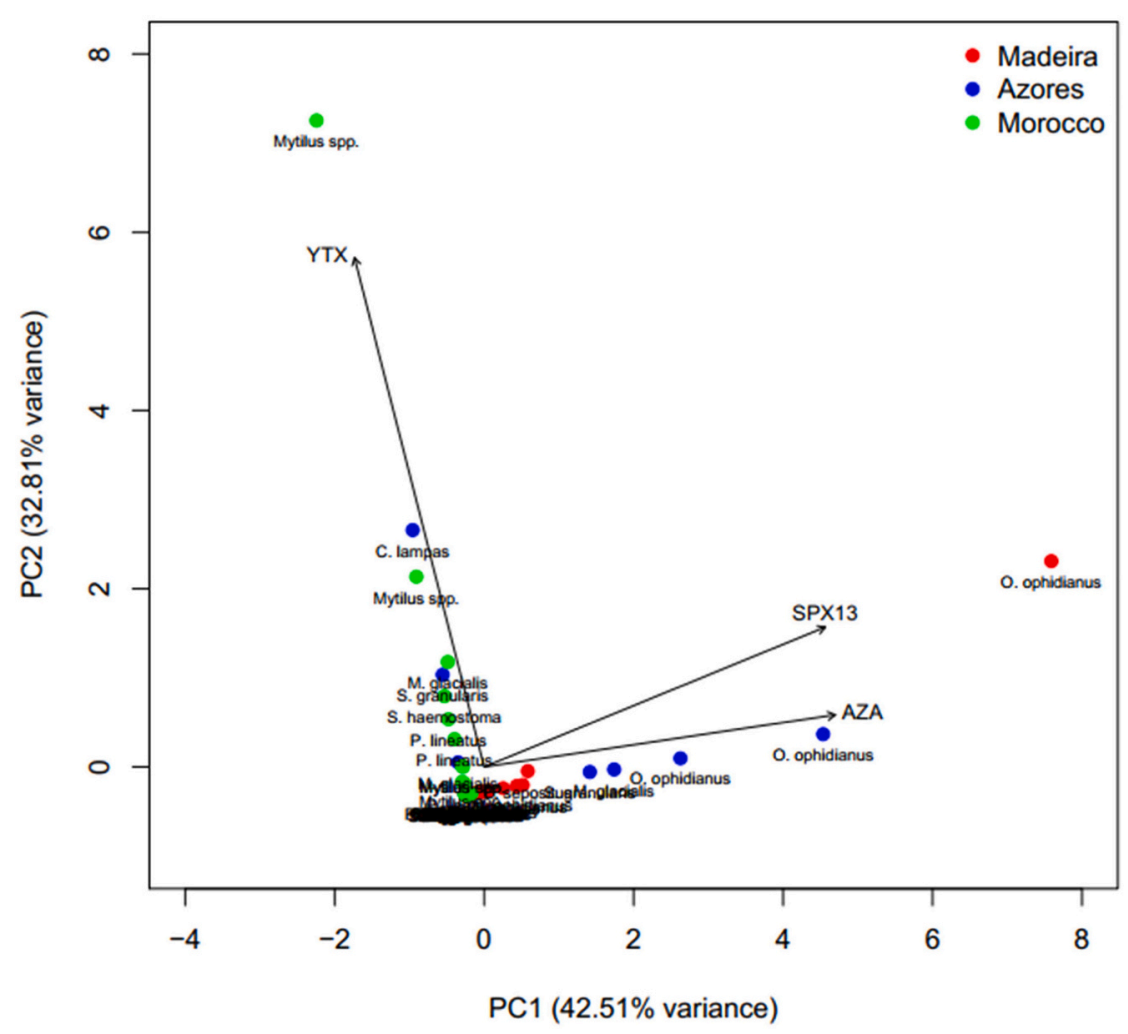

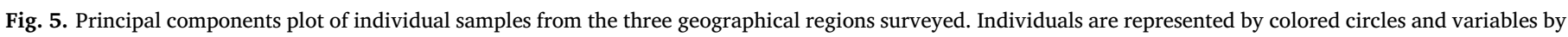
arrows. Individuals are labeled with the corresponding species name.

organisms is a simplistic approach and underestimates human health risk (Silva et al., 2015a; Silva et al., 2018; Silva et al., 2015c).

Although acute intoxications have been mitigated by the implementation of monitoring plans, there is still much to unravel regarding the marine biotoxins field, and risk assessment should be re-evaluated. Knowledge on chronical exposure are scarce, and an effort should be done on information gathering to upgrade tolerable daily intake doses as well as regulated levels. Academy and Health sector should be closer in order to promote the collection of epidemiological data, all enhancing the improvement of consumers protection. In the present work, four lipophilic toxin groups were detected in edible and non-edible species, though the threat of edible species is fast-forward to understand, non-edible species pose an indirect but probably higher threat, since marine toxins can be biomagnified along with the food web and transferred to the offspring, contributing to the imbalance of the food chain and consequently the ecosystem (Lin and Hwang, 2001; Roué et al., 2016; Silva et al., 2013; Silva et al., 2015b).

It is noteworthy to mention that some samples displayed the presence of more than one group of toxins, samples \#353 corresponding $E$. sepositus, was positive for the four screened groups, \#447 corresponding to $S$. haemostona was positive both in AZA and YTX groups, this also emphasizes the need to investigate what impact of toxic combinations in human health, even at sub-lethal dosages.

Also, it is important to highlight that lipophilic toxins were detected in commercial species (P. aspera, P. ordinaria, C. lampas, $P$. pollicipes, $H$. tuberculata, and $P$. lividus), although in concentrations below the recommended values given by EFSA (Alexander et al., 2008b; Alexander et al. 2008c; European Food Safety Authority, 2009, 2010). Despite this, we stress the need for revision and update of present legislation policies, and we hope that our data helps to take the necessary step forward.

\section{Conclusions}

An sampling effort translated in the harvesting of 101 samples belonging to 24 different benthic organisms in three different locations
(Madeira Island, São Miguel Island and northwestern Moroccan coast), during 2012 and 2013, aiming to determine new vectors for four groups of lipophilic toxins (YTX, AZA, SPXs and PTX) using UHPLC-MS/MS technique. With $80 \%$ of positive hits, we report a total of 19 new vectors, $53 \%$ of them gastropods (P. ordinaria, P. aspera, A. depilans, S. haemostoma, U. umbraculum, H. tuberculata, P. lineatus, G. umbilicalis, C. vulgatum, C. lampas), $42 \%$ of them echinorderms (P. lividus, A. aranciacus, $O$. ophidianus, M. glacialis, A. lixula, S. granularis, E. sepositus, D. africanum) and $5 \%$ crustaceans ( $P$. pollicipes). All detected values were below the recommended EFSA limits and ranged from 0.08 and $124.91 \mu \mathrm{g} / \mathrm{kg} \mathrm{SM}$. PTX-2 was only detected in a single starfish sample from Madeira, in contrast, the AZA group was the more prevalent in all sampling sites. Geographical tendencies were detected, materializing in a south-north gradient regarding the presence of these phycotoxins. Since consumer's preferences in gastropods, echinoderms and crustaceans is a growing tendency in the last few years, it is a major concern to update monitoring policies and legislations regarding limit uptake values.

We hope our work represents a step forward to better understand the real risks for human and environmental health.

\section{CRediT authorship contribution statement}

M.S. and V.V. conceived the idea, M.S. performed the sampling, M.S. and I.R. performed the sample analyses and wrote the paper. A.B. contributed to the experimental design and statistical analyses. M.H. collaborated in sample collection. A.A. contributed with experimental design. V.V. and L.M.B. contributed to funding and to materials and analyses tools. V.V., B.S., A.I.N., and M.K. collaborated in the sample collection and provided sampling and laboratory facilities. All authors participated in proof reading of the manuscript.

\section{Declaration of competing interest}

The authors declare that they have no known competing financial 
interests or personal relationships that could have appeared to influence the work reported in this paper.

\section{Acknowledgments}

This research was partially funded by the Portuguese Foundation of Science and Technology (FCT) project UID/Multi/04423/2013 and by the projects ALERTOXNET (EAPA_317/2016), funded by the Interreg Atlantic program. The research leading to these results has received funding from the following FEDER co-funded grants. From Consellería de Cultura, Educación e Ordenación Universitaria, Xunta de Galicia, 2017 GRC GI1682 (ED431C 2017/01). From Ministerio de Ciencia e Innovación ISCIII/ PI16/01830 and IISCIII/PI19/001248. From European Union Interreg AlertoxNet EAPA-317-2016, Interreg Agritox EAPA-998-2018, and H2020 778069-EMERTOX. Sandra Gegunde was supported by a fellowship from FIDIS, Spain. Additional funding was provided by National Funds through FCT—Fundação para a Ciência e a Tecnologia, under the projects UID/ BIA/00329/2013, 2015-2018 and UID/BIA/00329/2019. This is a contribution to project MIMAR MAC/4.6d/066 funded by the EU program INTERREG MAC 2014-2020. MS acknowledges FCT (SFRH/BD/73269/ 2010).

\section{References}

Alam, M., Shimizu, Y., Ikawa, M., Sasner, J.J., 1978. Reinvestigation of the toxins from the blue-green alga, Aphanizomenon flos-aquae, by a high performance chromatographic method. Journal of Environmental Science and Health 13 (7).

Alexander, J., Auðunsson, G.A., Benford, D., Cockburn, A., Cravedi, J.P., Dogliotti, E., Di Domenico, A., Fernández-Cruz, M.L., Fink-Gremmels, J., Fürst, P., Galli, C., Grandjean, P., Gzyl, J., Heinemeyer, G., Johansson, N., Mutti, A., Schlatter, J., van Leeuwen, R., Van Peteghem, C., Verger, P., 2008a. Opinion of the Scientific Panel on Contaminants in the Food chain on a request from the European Commission on marine biotoxins in shellfish - okadaic acid and analogues. The EFSA Journal 589, $1-62$.

Alexander, J., Benford, D., Cockburn, A., Cravedi, J.P., Dogliotti, E., Di Domenico, A. Férnandez-Cruz, M.L., Fink-Gremmels, J., Fürst, P., Galli, C., Grandjean, P., Gzyl, J., Heinemeyer, G., Johannessen, J.N., Mutti, A., Schlatter, J., Leeuween, R., Peteghem, C., Verger, P., 2008b. Opinion of the Scientific Panel on Contaminants in the Food chain on a request from the European Commission on marine biotoxins in shellfish yessotoxin group. EFSA J. 907, 1-62.

Alexander, J., Benford, D., Cockburn, A., Cravedi, J.P., Dogliotti, E., Domenico, A.D. Fernández-Cruz, M.L., Fink-Gremmels, J., Fürst, P., Galli, C., Grandjean, P., Gzyl, J., Heinemeyer, G., Johansson, N., Mutti, A., Schlatter, J., Leeuween, R., Peteghem, C., Verger, P., 2008c. Opinion of the Scientific Panel on Contaminants in the Food chain on a request from the European Commission on marine biotoxins in shellfish Azaspiracids. EFSA J. 723, 1-52.

Alexander, J., Auðunsson, G.A., Benford, D., Cockburn, A., Cravedi, J.P., Dogliotti, E., Di Domenico, A., Fernández-Cruz, M.L., Fink-Gremmels, J., Fürst, P., Galli, C., Grandjean, P., Gzyl, J., Heinemeyer, G., Johansson, N., Mutti, A., Schlatter, J., van Leeuwen, R., Van Peteghem, C., Verger, P., 2009a. Scientific Opinion of the Panel on Contaminants in the Food Chain on a request from the European Commission on marine biotoxins in shellfish - saxitoxin group. The EFSA Journal 1019, 1-76.

Alexander, J., Benford, D., Boobis, A., Ceccatelli, S., Cravedi, J.P., Di Domenico, A. Doerge, D., Dogliotti, E., Edler, L., Farmer, P., Filipič, M., Fink-Gremmels, J., Fürst, P., Guerin, T., Knutsen, H.K., Livesey, C., Machala, M., Mutti, A., Schlatter, J., van Leeuwen, R., Verger, P., 2009b. Scientific Opinion of the Panel on Contaminants in the Food Chain on a request from the European Commission on marine biotoxins in shellfish - domoic acid. The EFSA Journal 1181, 1-61.

Alexander, J., Benford, D., Boobis, A., Ceccatelli, S., Cravedi, J.P., Di Domenico, A., Doerge, D., Dogliotti, E., Edler, L., Farmer, P., Filipič, M., Fink-Gremmels, J., Fürst, P., Guerin, T., Knutsen, H.K., Machala, M., Mutti, A., Schlatter, J., van Leeuwen, R., 2010. EFSA Panel on Contaminants in the Food Chain; Scientific Opinion on marine biotoxins in shellfish - emerging toxins: Ciguatoxin group. EFSA J. 1627, 1-38.

Amzil, Z., Sibat, M., Royer, F., Masson, N., Abadie, E., 2007. Report on the first detection of pectenotoxin-2, spirolide-a and their derivatives in French shellfish. Marine drugs 5,12 .

Backer, L.C., Schurz Rogers, H., Fleming, L.E., Kirkpatrick, B., Benson, J., 2005. Phycotoxins in marine seafood. In: Sikorski, Z.E., Dabrowski, W.M. (Eds.), Chemical and Functional Properties of Food Components: Toxins in Food. CRC Press, Boca Rotan, FL, USA, pp. 155-190 CRC Press, Boca Raton, FL, USA.

Bialojan, C., Takai, A., 1988. Inhibitory effect of a marine sponge toxin, okadaic acid, on protein phosphatases. Biochem. J. 256, 283-290.

Bianchi, C., Fato, R., Angelin, A., Trombetti, F., Ventrella, V., Borgatti, A.R., Fattorusso, E., Ciminiello, P., Bernardi, P., Lenaz, G., Parenti, C.G., 2004. Yessotoxin, a shellfish biotoxin, is a potent inducer of the permeability transition in isolated mitochondria and intact cells. Biochim. Biophys. Acta 1656, 139-147.

Bourne, Y., Radic, Z., Araoz, R., Talley, T.T., Benoit, E., Servent, D., Taylor, P., Molgo, J., Marchot, P., 2010. Structural determinants in phycotoxins and AChBP conferring high affinity binding and nicotinic AChR antagonism. Proc. Natl. Acad. Sci. U. S. A. $107,6$.

Bulleri, F., Benedetti-Cecchi, L., Cinelli, F., 1999. Grazing by the sea urchins Arbacia lixula L. and Paracentrotus lividus Lam. In the Northwest Mediterranean. J. Exp. Mar. Biol. Ecol. 241, 81-85.

Burla, H., Ferlin, V., Pabst, B., Ribi, G., 1972. Notes on the ecology of Astropecten aranciacus. Mar. Biol. 14, 235-241.

Buschbaum, C., Dittmann, S., Hong, J.-S., Hwang, I., Strasser, M., Thiel, M., Valdivia, N., Yoon, S., Reise, K., 2008. Mytilid mussels: global habitat engineers in coastal sediments. Helgol. Mar. Res. 63, 47-58.

Carefoot, T.H., 1987. Aplysia: its biology and ecology. Oceanogr. Mar. Biol. Annu. Rev. $25,167-284$.

Cembella, A.D., 2003. Chemical ecology of eukaryotic microalgae in marine ecosystems. Phycologia 42, 420-447.

Cheng, Y.S., Villareal, T.A., Zhou, Y., Gao, J., Pierce, R.H., Wetzel, D., Naar, J., Baden, D.G., 2005. Characterization of red tide aerosol on the Texas coast. Harmful Algae 4, 87-94.

Ciminiello, P., Fattorusso, E., Forino, M., Magno, S., Poletti, R., Satake, M., Viviani, R., Yasumoto, T., 1997. Yessotoxin in mussels of the northern Adriatic Sea. Toxicon 35, 177-183.

Conley, D.J., Björck, S., Bonsdorff, E., Carstensen, J., Destouni, G., Gustafsson, B.G., Hietanen, S., Kortekaas, M., Kuosa, H., Meier, H.E.M., Müller-Karulis, B., Nordberg, K., Norkko, A., Nürnberg, G., Pitkänen, H., Rabalais, N.N., Rosenberg, R., Savchuk, O.P., Slomp, C.P., Voss, M., Wulff, F., Zillén, L., 2009. Critical review: hypoxia-related processes in the Baltic Sea. Environ. Sci. Technol. 43, 3412-3420.

Crothers, J.H., 2001. Common topshells: an introduction to the biology of Osilinus lineatus with notes on other species in the genus. Field Stud. 10, 115-160.

Dayrat, B., 2009. Review of the current knowledge of the systematics of onchidiidae (mollusca: Gastropoda: Pulmonata) with a checklist of nominal species. Zootaxa 2068, 1-26.

Eiki, K., Satake, M., Koike, K., Ogata, T., Mitsuya, T., Oshima, Y., 2005. Confirmation of yessotoxin production by the dinoflagellate Protoceratium reticulatum in Mutsu Bay. Fish. Sci. 71, 633-638.

Espina, B., Louzao, M.C., Ares, I.R., Cagide, E., Vieytes, M.R., Vega, F.V., Rubiolo, J.A., Miles, C.O., Suzuki, T., Yasumoto, T., Botana, L.M., 2008. Cytoskeletal toxicity of pectenotoxins in hepatic cells. Br. J. Pharmacol. 155, 934-944.

Etheridge, S.M., 2010. Paralytic shellfish poisoning: seafood safety and human health perspectives. Toxicon: Official Journal of the International Society on Toxinology $56,15$.

European Food Safety Authority, E, 2009. Marine biotoxins in shellfish- Pectenotoxin group. EFSA J. 1109, 48.

European Food Safety Authority, E, 2010. Marine biotoxins in shellfish - cyclic imines (spirolides, gymnodimines, pinnatoxins and pteriatoxins). EFSA J. 8, 62.

European Union Refenrence Laboratory for Marine Biotoxins, E, 2013. Harmonized Standard Operating Procedure for Detection of Lipophilic Toxins by Mouse Bioassay. Version 6.

European Union Reference Laboratory for Marine Biotoxins, E, 2015. Standard Operating Procedure for Determination of Lipophilic Marine Biotoxins in Molluscs by LC-MS/ MS Version 5.

FAO, 2015. Fishery and aquaculture statistics. Global capture production 1950-2013 (FishstatJ). In: FAO Fish Aquac Dep Rome Updat 2016.

FAO/IOC/WHO, 2004. Report of the Joint FAO/IOC/WHO Ad Hoc Expert Consultation on Biotoxins in Bivalve Mollusks.

Faria, J., Martins, G.M., Pita, A., Ribeiro, P.A., Hawkins, S.J., Presa, P., Neto, A.I., 2017. Disentangling the genetic and morphological structure of Patella candei complex in Macaronesia (NE Atlantic). Ecological Evolution 7.

Ferguson, J.C., 1969. Feeding activity in Echinaster and its induction with dissolved nutrients. Biol. Bull. 136, 374-384.

Fleming, L.E., Katz, D., Bean, J.A., Hammond, R., 2001. Epidemiology of seafood poisoning. In: Hui, Y.H., Kitts, D., Stanfield, S. (Eds.), Foodborn Disease Handbook: Seafood and Environmental Toxins. Marcel Dekker, New York, U.S.A, pp. 288-306.

Fleming, L.E., Backer, L.C., Baden, D.G., 2005. Overview of aerosolized Florida red tide toxins: exposures and effects. Environ. Health Perspect. 113, 618-620.

Gerssen, A., Mulder, P.P., McElhinney, M.A., de Boer, J., 2009. Liquid chromatographytandem mass spectrometry method for the detection of marine lipophilic toxins under alkaline conditions. J. Chromatogr. A 1216, 10.

Gerssen, A., Bovee, T., Klijnstra, M., Poelman, M., Portier, L., Hoogenboom, R., 2018. First report on the occurrence of tetrodotoxins in bivalve mollusks in the Netherlands. Toxins 10, 450.

Hallegraeff, G.M., 1993. Algal blooms are not a simple toxic broth. Search 24, 179.

Hallegraeff, G.M., 2010. Ocean climate change, phytoplankton community responses, and harmful algal blooms: a formidable predictive challenge. J. Phycol. 46, 220-235.

Heisler, J.P., Gilbert, J., Burkholder, J., Anderson, D., Cochlan, W., Dennison, W., Dortch, Q., Gobler, C.J., Heil, C., Humphries, E., Lewitus, A., Magnien, R., Marshall, H., Sellner, K., Stockwell, D., Stoecker, D., Suddleson, M., 2008. Eutrophication and harmful algal blooms: scientific consensus. Harmful Algae 8, 3-13.

Hess, P., McMahon, T., Slattery, D., Swords, D., Dowling, G., McCarron, M., Clarke, D., Gibbons, W., Silke, J., O'Cinneide, M., 2003. Use of LC-MS testing to identify lipophilic toxins, to establish local trends and interspecies differences and to test the comparability of LC-MS testing with the mouse bioassay: an example from the Irish biotoxin monitoring programme 2001. In: Villalba, A., Reguera, B., Romalde, J.L., Beiras, R. (Eds.), Molluscan Shellfish Safety. Consellería de Pesca e Asuntos Marítimos da Xunta de Galicia Intergovernmental Oceanographic Commission of UNESCO, Santiago de Compostela, Spain.

Hoagland, P., Scatasta, S., 2006. Ecology on harmful algae. In: Graneli, E., Turner, T. (Eds.), The Economic Effect of Harmful Algal Blooms. Springer, Berlin, Germany, pp. 
$391-402$.

Hu, T., Curtis, J.M., Oshima, Y., Quilliam, M.A., Walter, J.A., Watson-Wright, W.M. Wright, J.L.C., 1995. Spirolides B and D, two novel macrocycles isolated from the digestive glands of shellfish. J Chem Soc Chem Comm 3.

Kaufmann, M.J., Santos, F., Maranhão, M., 2015. Checklist of nanno- and microphytoplankton off Madeira Island (Northeast Atlantic) with some historical notes. Nova Hedwigia 101, 205-232.

Knox, G.A., 2001. Hard shores. In: Kennish, M.J. (Ed.), The Ecology of Seashores. CRC Press, Boca Raton, Florida, USA, pp. 20-86.

Konishi, M., Yang, X., Li, B., Fairchild, C.R., Shimizu, Y., 2004. Highly cytotoxic metabolites from the culture supernatant of the temperate dinoflagellate Protoceratium cf. reticulatum. J. Nat. Prod. 67, 1309-1313.

Krock, B., Tillmann, U., John, U., Cembella, A., 2008. LC-MS-MS aboard ship: tandem mass spectrometry in the search for phycotoxins and novel toxigenic plankton from the North Sea. Anal. Bioanal. Chem. 392, 797-803.

Krock, B., Tillmann, U., John, U., Cembella, A., 2009. Characterization of azaspiracids in plankton size-fractions and isolation of an azaspiracid-producing dinoflagellate from the North Sea. Harmfull Algae 8, 10.

Krock, B., Tillmann, U., Tebben, J., Trefault, N., Gu, H., 2019. Two novel azaspiracids from Azadinium poporum, and a comprehensive compilation of azaspiracids produced by Amphidomataceae, (Dinophyceae). Harmful Algae 82, 1-8.

Lê, S., Josse, J., Husson, F., 2008. FactoMineR: an R package for multivariate analysis. J. Stat. Softw. 25, 1-18.

Lee, J.-S., Tangen, K., Dahl, E., Hovgaard, P., Yasumoto, T., 1988. Diarrhetic shellfish toxins in Norwegian mussels. Bull. Jpn. Soc. Sci. Fish. 54, 1953-1957.

Lemée, R., Boudouresque, C.F., Gobert, J., Malestroit, P., Mari, X., Meinesz, A., Menager, V., Ruitton, S., 1995. Feeding behaviour of Paracentrotus lividus in the presence of Caulerpa taxifolia introduced in the Mediterranean Sea. Oceanol. Acta 19, 245-253.

Lin, S.J., Hwang, D.F., 2001. Possible source of tetrodotoxin in the starfish Astropecten scoparius. Toxicon 39, 573-579.

Marrouchi, R., Dziri, F., Belayouni, N., Hamza, A., Benoit, E., Molgo, J., Kharrat, R., 2010. Quantitative determination of gymnodimine-a by high performance liquid chromatography in contaminated clams from Tunisia coastline. Marine biotechnology (New York, N.Y.) 12, 7.

Martinez-Pita, I., Sanches-Espana, A., Garcia, F.J., 2008. Gonadal growth and reproduc tion in the sea urchin Sphaerechinus granularis (Lamarck 1816) in southern Spain. Sci. Mar. 72, 603-611.

McMahon, T., Silke, J., 1996. Winter toxicity of unknown aetiology in mussels. Harmful Algae News 14, 1

Meilert, K., Brimble, M.A., 2006. Synthesis of the bis-spiroacetal moiety of the shellfish toxins spirolides B and D using an iterative oxidative radical cyclization strategy. Organic \& biomolecular chemistry 4, 9 .

Molgó, J., Aráoz, R., Benoit, E., Iorga, B.I., 2014. Cyclic imine toxins: chemistry, origin, metabolism, pharmacology, toxicology and detection. In: Botana, L.M. (Ed.), Seafood and Freshwater Toxins: Pharmacology, Physiology and Detection, 3rd edition. Taylor and Francis, Boca Raton, FL, pp. 951-990.

Moore, S.K., Trainer, V.L., Mantua, N.J., Parker, M.S., Laws, E.A., Backer, L.C., Fleming, L.E., 2008. Impacts of climate variability and future climate change on harmful algal blooms and human health. Environ. Health 7, S4.

Morgan, K.L., Larkin, S.L., Adams, C.M., 2009. Firm-level economic effects of HABS: a tool for business loss assessment. Harmful Algae 8, 212-218.

Murata, M., Masanori, K., Lee, J.-S., Yasumoto, T., 1987. Isolation and structure of Yessotoxin, a novel polyether compound implicated in diarrhetic shellfish poisoning. Tetrahedron Lett. 28, 5869-5872.

Navarro, P.G., García-Sanz, S., Barrio, J.M., Tuya, F., 2013. Feeding and movement patterns of the sea cucumber Holothuria sanctori. Mar. Biol. 160, 2957-2966.

Nicolaidou, A., Nott, J.A., 1999. The role of the marine gastropod Cerithium vulgatum in the biogeochemical cycling of metals. Biogeochemical Cycling and Sediment Ecology 59, 137-146.

Ogino, H., Kumagai, M., Yasumoto, T., 1997. Toxicologic evaluation of yessotoxin. Nat. Toxins 5, 255-259.

Otero, P., Alfonso, A., Alfonso, C., Vieytes, M.R., Louzao, M.C., Botana, A.M., Botana, L.M., 2010. New protocol to obtain spirolides from Alexandrium ostenfeldii cultures with high recovery and purity. Biomed. Chromatogr. 24, 878-886.

Otero, A., Chapela, M.J., Atanassova, M., Vieites, J.M., Cabado, A.G., 2011a. Cyclic imines: chemistry and mechanism of action: a review. Chem. Res. Toxicol. 24, 13 .

Otero, P., Alfonso, A., Alfonso, C., Araoz, R., Molgo, J., Vieytes, M.R., Botana, L.M., 2011b. First direct fluorescence polarization assay for the detection and quantification of spirolides in mussel samples. Anal. Chim. Acta 701, 10.

Paz, B., Riobó, P., Fernández, M.L., Fraga, S., Franco, J.M., 2004. Production and release of yessotoxins by the dinoflagellates Protoceratium reticulatum and Lingulodinium polyedrum in culture. Toxicon 44, 251-258.

Peck, L.S., 1989. Feeding, growth and temperature in the ormer, Haliotis tuberculata L Progress in Underwater Science 14, 95-107.

Pérez-Gómez, A., Novelli, A., Ferrero-Gutiérrez, A., Franco, J.M., Paz, B., FernándezSánchez, M.T., 2006. Potent neurotoxic action of the shellfish biotoxin yessotoxin on cultured cerebellar neurons. Toxicol. Sci. 90, 168-177.

Ramírez, R., Tuya, F., Haroun, R.J., 2009. Spatial patterns in the population structure of the whelk Stramonita haemastoma (Linnaeus, 1766) (Gastropoda: Muricidae) in the Canarian Archipelago (eastern Atlantic). Sci. Mar. 73, 431-437.

Reverté, L., Soliño, L., Carnicer, O., Diogène, J., Campàs, M., 2014. Alternative methods for the detection of emerging marine toxins: biosensors, biochemical assays and cellbased assays. Marine Drugs 12, 5719-5763.

Rhodes, L., McNabb, P., de Salas, M., Briggs, L., Beuzenberg, V., Gladstone, M., 2006. Yessotoxin production by Gonyaulax spinifera. Harmful Algae 5, 148-155.

Rodríguez, A., Hernández, J.C., Clemente, S., Coppard, S.E., 2013. A new species of Diadema (Echinodermata: Echinoidea: Diadematidae) from the eastern Atlantic Ocean and a neotype designation of Diadema antillarum (Philippi, 1845). Zootaxa 3636, 144-170.

Roué, M., Darius, H.T., Picot, S., Ung, A., Viallon, J., Gaertner-Mazouni, N., Sibat, M., Amzil, Z., Chinain, M., 2016. Evidence of the bioaccumulation of ciguatoxins in giant clams (Tridacna maxima) exposed to Gambierdiscus spp. cells. Harmful Algae 57, 78-87.

Seki, T., Satake, M., Mackenzie, L., Kaspar, H.F., Yasumoto, T., 1995. Gymnodimine, new marine toxin of unprecedented structure isolated from New Zealand oysters and the dinoflagellate, Gymnodinium sp. Tetrahedron Lett. 36, 4.

Silva, M., Barreiro, A., Rodriguez, P., Otero, P., Azevedo, J., Alfonso, A., Botana, L.M., Vasconcelos, V., 2013. New invertebrate vectors for PST, spirolides and okadaic acid in the North Atlantic. Marine Drugs 11, 1936-1960.

Silva, M., Pratheepa, V.K., Botana, L.M., Vasconcelos, V., 2015a. Emergent toxins in North Atlantic temperate waters: a challenge for monitoring programs and legislation. Toxins 7, 859-885.

Silva, M., Rodriguez, I., Barreiro, A., Kaufmann, M., Isabel Neto, A., Hassouani, M., Sabour, B., Alfonso, A., Botana, L.M., Vasconcelos, V., 2015b. New invertebrate vectors of Okadaic acid from the North Atlantic Waters-Portugal (Azores and Madeira) and Morocco. Toxins (Basel) 7, 5337-5347.

Silva, M., Rodriguez, I., Barreiro, A., Kaufmann, M., Neto, A.I., Hassouani, M., Sabour, B. Alfonso, A., Botana, L.M., Vasconcelos, V.x., 2015c. First report of ciguatoxins in two starfish species: Ophidiaster ophidianus and Marthasterias glacialis. Toxins 7 , 3740-3757.

Silva, M., Rey, V., Barreiro, A., Kaufmann, M., Neto, A.I., Hassouani, M., Sabour, B., Botana, A., Botana, L., Vasconcelos, V., 2018. Paralytic shellfish toxins occurrence in non-traditional invertebrate vectors from North Atlantic Waters (Azores, Madeira, and Morocco). Toxins 10, 362.

Smayda, T.J., 1997. What is a bloom? A commentary. Limnol. Oceanogr. 42, 1132-1136.

Stobo, L.A., Lewis, J., Quilliam, M.A., Hardstaff, W.R., Gallacher, S., Webster, L., Smith, E., McKenzie .S.M.I.B. (Eds.), 2003. Detection of Yessotoxin in UK and Canadian Isolates of Phytoplankton and Optimization and Validation of LC-MS Methods. Gulf Fisheries Centre, Moncton, New Brunswick, Canada 2003.

Suzuki, T., 2008. Chemistry, metabolism and chemical detection methods of pectenotoxins. In: Botana, L.M. (Ed.), Seafood and Freshwater Toxins: Pharmacology, Physiology and Detection, 2nd edition. Taylor and Francis, Boca Raton, FL, pp. 343-360.

Takahashi, N., Iwanaga, T., Aizawa, H., Koto, H., Watanabe, K., Kishikawa, R., Ikeda, T., Shoji, S., Nishima, S., Hara, N., 2001. Acute interstitial pneumonia induced by ONO1078 (pranlukast), a leukotriene receptor antagonist. Intern. Med. 40, 791-794.

Tillmann, U., Elbrächter, M., Krock, B., John, U., Cembella, A., 2009. Azadinium spinosum gen. et sp. nov. (Dinophyceae) identified as a primary producer of azaspiracid toxins. Eur. J. Phycol. 44, 17.

Toral-Granda, V., Lovatelli, A., Vasconcellos, M., 2008. Scientific Committee composed of Conand C., Hamel J.F., Mercier A., Purcell S. and Uthicke S. - International Workshop on the Sustainable Use and Management of Sea Cucumber Fisheries, SPC BechedeMer Information Bulletin, Puerto Ayora, Galapagos Islands, Ecuador.

Tubaro, A., Durando, P., Del Favero, G., Ansaldi, F., Icardi, G., Deeds, J.R., Sosa, S., 2011 Case definitions for human poisonings postulated to palytoxins exposure. Toxicon 57 478-495.

Valdes, A., 2001. On the publication data, authorship, and type species of Umbraculum and Tylodina Gastropoda; Opisthobranchia; Tylodinoidea. The Nautilus 115, 29-34.

Vershinin, A., Moruchkov, A., Morton, S.L., Leighfield, T.A., Quilliam, M.A., Ramsdell, J.S., 2006. Phytoplankton composition of the Kandalaksha Gulf, Russian White Sea: Dinophysis and lipophilic toxins in the blue mussel (Mytilus edulis). Harmful Algae 5, 558-564.

Villar Gonzalez, A., Rodriguez-Velasco, M.L., Ben-Gigirey, B., Botana, L.M., 2006. First evidence of spirolides in Spanish shellfish. Toxicon: Official Journal of the International Society on Toxinology 48, 7.

Yang, C.Z., Albright, L.J., 1992. Effects of the harmful diatom Chaetoceros concavicornis on respiration of rainbow trout Oncorhynchus mykiss. Dis. Aquat. Org. 14, 105-114.

Yasumoto, T., Takizawa, A., 1997. Fluorometric measurement of yessotoxins in shellfish by highpressure liquid chromatography. Biosci. Biotechnol. Biochem. 61, 1775-1777.

Yasumoto, T., Oshima, Y., Yamaguchi, M., 1978. Occurrence of a new type of shellfish poisoning in the Tohoku district [Japan]. Bull Jap Soc Sci Fish 44, 7.

Yotsu-Yamashita, M., Sugimoto, A., Terakawa, T., Shoji, Y., Miyazawa, T., Yasumoto, T., 2001. Purification, characterization, and cDNA cloning of a novel soluble saxitoxin and tetrodotoxin binding protein from plasma of the puffer fish, Fugu pardalis. Eur. J. Biochem. 268, 5937-5946. 